\title{
Stimulasi Minat Belajar Agama Islam Menggunakan Strategi Cerita Pada Siswa SMP IT Al-Asror Sekampung Lampung Timur
}

\section{Ikhwanul Amri, Akla, Muhammad Ali}

\author{
Institut Agama Islam Negeri (IAIN) Metro
}

Jl. Ki Hajar Dewantara No.15A, Iringmulyo, Kec. Metro Tim., Kota Metro, Lampung.

e-mail :amrinob@gmail.com,akla@metrouniv.ac.id, dan m.ali@metrouniv.ac.id,

\begin{tabular}{|c|c|c|}
\hline Diterima: & Revisi: & Disetujui: \\
24 Januari 2020 & 16 Februari 2020 & 10 April 2020 \\
\hline DOI: & https://doi.org/DOI.10.32332/tarbawiyah.v4i1.2228 \\
\hline
\end{tabular}

Abstract

Keyword

Abstrak
This study aimed to analyze student's learning interest and the learning process of Islamic education by using story strategies. This research was an experimental research that was applying learning using story strategies to the experimental group for several meetings. The sample in this study were 30 students of class VIII at SMP IT Al-Asror Sekampung. The research sample was classified into two groups; the experimental and the control group. The experimental group was a group of students taught by story strategies. The control group was a group of students taught by conventional strategies. The results showed that the use of story strategies in the learning process of Islamic education has been able to overcome student learning problems. The story strategy has been able to arouse enthusiasm and student attention. Curiosity to the storyline encourages students to always pay attention and concentrate on the story being heard. The results of statistical tests on the questionnaire data indicate there was an influence significant use of story strategies on student learning interests. High learning interest would have an impact on the achievement of learning objectives.

\section{Interest in Learning PAI; Story Strategy; and Learning} Motivation

Penelitian ini bertujuan untuk menganalisis minat belajar siswa dan proses pembelajaran pendidikan Islam dengan menggunakan strategi cerita. Penelitian ini adalah penelitian eksperimental yang menerapkan pembelajaran menggunakan strategi cerita untuk kelompok eksperimen untuk beberapa pertemuan. Sampel dalam penelitian ini adalah 30 siswa kelas VIII di SMP IT Al-Asror Sekampung. Sampel penelitian diklasifikasikan menjadi dua kelompok; kelompok eksperimen dan kontrol. Kelompok eksperimen adalah sekelompok siswa yang diajar dengan strategi 
cerita. Kelompok kontrol adalah sekelompok siswa yang diajar dengan strategi konvensional. Hasil penelitian menunjukkan bahwa penggunaan strategi cerita dalam proses pembelajaran pendidikan Islam telah mampu mengatasi masalah belajar siswa. Strategi cerita telah mampu membangkitkan antusiasme dan perhatian siswa. Keingintahuan akan alur cerita mendorong siswa untuk selalu memperhatikan dan berkonsentrasi pada cerita yang didengar. Hasil tes statistik pada data kuesioner menunjukkan ada pengaruh penggunaan strategi cerita yang signifikan terhadap minat belajar siswa. Minat belajaryang tinggi akan berdampak pada pencapaian tujuan pembelajaran.

Kata Kunci Minat Belajar PAI; Strategi Cerita; dan Motivasi Belajar

\section{A. Pendahuluan}

Pembelajaran Pendidikan Agama Islam (PAI) pada siswa menghadapai berbagai problema yang bermuara pada tidak tercapainya tujuan pembelajaran. Beberapa problema yang dihadapi siswa yaitu rendahnya semangat belajar, minat belajar yang kurang, keinginan belajar yang rendah, siswa merasa cepat bosan yang berdampak pada hasil belajar yang tidak memuaskan. Penelitian Susiana menjelaskan bahwa problem pembelajaran PAI pada siswa terkait dengan minat dan konsentrasi belajar yang berbeda antara siswa satu dan yang lain yang berdampak pada tingkat pencapain yang tidak maksimal. ${ }^{1}$ Problem ini berdampak pada pemuasan hasil belajar PAI yang rendah. Dalam penelitian Susiana menunjukkan 30\% siswa mendapatkan hasil belajar tinggi $20 \%$; sedang 50\% rendah, hal serupa juga dipertegas oleh penelitian Sopian Sinaga yang menunjukan hasil belajar PAI yang rendah disebabkan rendahnya semangat belajar, minat belajar yang kurang yang berdampak pada hasil belajar siswa yang tidak maksimal. ${ }^{2}$

Problema pembelajaran PAI diidentifikasi berasal dari dua problem utama yaitu: Pertama, Strategi cerita yang monoton, pembelajaran yang monoton berarti pembelajaran yang dilakukan begitu saja tanpa adanya hal yang berbeda dari cara penyampaian

1 Susiana Susiana, "Problematika Pembelajaran PAI Di SMKN 1 Turen," Jurnal Pendidikan Agama Islam Al-Thariqah 2, no. 1 (2017): 73-88, https://doi. org/10.25299/ althariqah.2017.vol2(1).648.

2 Sopian Sinaga, "Problematika Pendidikan Agama Islam Di Sekolah Dan Solusinya" II, no. 1 (2017): 175-88. 
materinya. Pembelajaran yang monoton membuat siswa menjadi tidak aktif dan merasa jenuh ketika proses pembelajaran berlangsung sehingga membuat proses pembelajaran tidak berjalan efektif. Pembelajaran monoton tentunya menjadi suatu permasalahan yang ada dalam pendidikan. Guru harus bisa mengatasi permasalahan ini, yaitu dengan cara menggunakan beberapa strategi pembelajaran yang dapat membuat siswa menjadi lebih bersemangat dan aktif di dalam kelas. ${ }^{3}$ Kedua, Penggunaan strategi yang tidak relevan, kesalahan yang dilakukan sebagian besar guru dalam mengajar yaitu menggunakan strategi yang tidak relevan, hal tersebut mengakibatkan terhambatnya suatu proses pembelajaran, siswa kurang memahami tentang materi yang diajarkan. Dalam melakukan pembelajaran guru sebaiknya memilih strategi yang relevan dengan materi yang akan diajarkan agar proses pembelajaran dapat berlangsung dengan baik dan siswa mendapatkan hasil yang maksimal. ${ }^{4}$

Sejauh ini penelitian tentang pembelajaran PAI cenderung mengkaji dua isu pokok saja yaitu, pertama penelitian tentang profesionalitas guru dalam proses pembelajaran dengan penggunaan pendekatan yang menarik. Dalam upaya peningkatan mutu pendidikan, aspek utama yang ditentukan adalah kualitas guru. Hal ini disebabkan guru merupakan titik sentral dalam pembaharuan dan peningkatan mutu pendidikan, dengan kata lain salah satu faktor yang dapat meningkatkan mutu pendidikan yaitu apabila pelaksanaan proses pembelajaran dilakukan oleh guru yang dapat diandalkan keprofesionalannya. ${ }^{5}$ Kedua, penelitian yang melihat strategi sebagai instrumen untuk meningkatkan konsentrasi belajar. Kesiapan mental siswa akan mempengaruhi dalam proses menerima pelajaran yang dapat berakibat pada hasil belajar siswa. Seperti bakat, minat, perhatian dan konsentrasi siswa. Dalam konsentrasi belajar sangat diperlukannya kefokusan atau tingkat pemusatan pikiran di dalam suatu objek yang

${ }^{3}$ Noor Amirudin, "Problematika Pembelajaran Pendidikan Agama Islam Di Era Digital," Prosiding Seminar Nasional PAI Dengan Pendekatan Multidisipliner, 2019, 181-92.

4 Bach Yunof Candra, "Problematika Pendidikan Agama Islam," Journal Istighna 1, no. 1 (2019): 134-53, https://doi.org/10.33853/istighna.v1i1.21.

5 Tiara anggia Dewi, "Pengaruh Profesionalisme Guru Dan Motivasi Kerja Terhadap Kinerja Guru Ekonomi Sma Se-Kota Malang," PROMOSI Uurnal Pendidikan Ekonomi) 3, no. 1 (2015): 24-35, https://doi.org/10.24127/ja.v3i 1.148 .

Tarbawiyah: Jurnal Ilmiah Pendidikan :: Volume 04; Nomor 1, Juni 2020 
ada di hadapannya, yang sedang dipelajari dengan cara menghilangkan seluruh fikiran selain pada objek yang di fokuskan. Konsentrasi siswa menjadi prioritas guru dalam mengajar. ${ }^{6}$ Dari kedua isu pokok pada penelitian terdahulu, tampak aspek proses dengan memperhatikan mentalitas belajar siswa belum dikaji secara seksama. Pada analisis tersebut kurang ditujukan pada siswa SMP, penelitian yang ada lebih fokus pada siswa menengah atas.

Artikel ini akan mendeskripsikan dan membahas tentang pembelajaran PAI yang tidak hanya berorientasi pada tujuan semata. Namun, akan berusaha menganalisis secara seksama tingkat minat belajar siswa pada pelajaran PAI setelah diterapkan strategi cerita pada kelas VIII SMP IT Al-Asror Sekampung Lampung Timur dan bagaimana berpengaruhnya strategi cerita terhadap minat belajar siswa kelas VIII SMP IT Al-Asror Sekampung Lampung Timur.

\section{B. Minat Belajar dan Strategi Cerita dalam Pembelajaran}

Minat merupakan suatu arah yang dapat menumbuhkan semangat seseorang melakukan aktifitas tertentu. Minat adalah penerimaan sesuatu di luar dirinya sendiri, makin dekat hubungan tersebut makin besar minatnya untuk mencapai sesuatu. ${ }^{7}$ Dalam suatu pembelajaran, minat memiliki urgensitas. Hal ini didasarkan atas beberapa hal, yaitu; (1) memunculkan sikap serta merta; (2) memudahkan tercapainya konsentrasi; (3) memperkuat melekatnya materi pelajaran dalam ingatan; dan (4) mengurangi kebosanan belajar dalam diri individu.

Minat belajar sangat berpengaruh terhadap aktivitas belajar siswa. Minat yang dimiliki siswa terhadap suatu pelajaran maka siswa akan mempelajarinya dengan tekun, karena ada daya tarik terhadap pelajaran tersebut. Siswa mudah mengingat materi pelajaran yang menarik minatnya. Proses belajar akan berjalan efektif apabila disertai

6 Lestari Friska, "Meningkatkan Konsentrasi Belajar Siswa Dengan Menerapkan Pembelajaran Kontekstual Pada Pembelajaran Ipa," 2017.

${ }^{7}$ A. Amidah, "Strategi Guru Dalam Meningkatkan Minat Belajar Siswa Pada Mata Pelajaran Pendidikan Agama Islam Di Sekolah Dasar Negeri 147 Palembang," Conciencia 14, no. 2 (2014): 117-38, https://doi.org/10.19109/conciencia. v14i2.98. 
dengan minat. ${ }^{8}$ Minat menjadi salah satu faktor yang dapat mempengaruhi usaha yang dilakukan seseorang. Minat yang kuat akan menimbulkan usaha yang tekun dan serius serta tidak mudah putus asa dalam menghadapi tantangan. Jika seorang siswa memiliki rasa ingin belajar, ia akan cepat memahami dan mengingat apa yang sudah dipelajari. Minat belajar siswa adalah suatu rasa atau keinginan siswa untuk menekuni suatu mata pelajaran yang ia sukai.

Upaya yang dapat dilakukan dalam meningkatkan minat belajar siswa yaitu dengan menggunakan strategi belajar yang menarik. Pembelajaran yang menarik dapat melatih keterampilan siswa, seperti mendengar, berbicara, membaca, dan menulis. Agar strategi pembelajaran dapat mendukung aktifitas siswa bisa menggunakan strategi pembelajaran yang aktif dan tidak monoton agar dapat membantu meningkatkan minat belajar siswa yaitu salah satunya dengan menggunakan strategi pembelajaran cerita. ${ }^{9}$

Ketekunan belajar berhubungan dengan sikap dan minat siswa terhadap pelajaran. Jika pelajaran tidak menarik minat siswa karena suatu hal, maka siswa akan mengabaikannya apabila terdapat suatu kesulitan. Sebaliknya, jika suatu pelajaran menarik karena memberikan hasil yang menggembirakan, maka ia cenderung akan meluangkan waktu yang lebih banyak untuk tugas itu. Timbulnya minat tidak secara tiba-tiba melainkan timbul dari pengalaman dan kebiasaan pada saat belajar. Jadi minat akan selalu berhubungan dengan kebutuhan atau keinginan, oleh karena itu hal yang paling penting adalah bagaimana menciptakan kondisi agar siswa selalu butuh dan ingin terus belajar. ${ }^{10}$

Minat menjadi salah satu faktor yang mempengaruhi keberhasilan belajar. Minat tidak muncul dengan sendirinya tetapi

${ }^{8}$ Sufairi, "Pengaruh Strategi Pembelajaran Kooperatif Think Pair Share Dan Minat Belajar Terhadap Hasil Belajar Pendidikan Agama Islam Siswa Sekolah Dasar Negeri 104192 Tandem Hilir II Deli Serdang" 3, no. 1 (2019): 129-39.

9 Rosidah, "Upaya Meningkatkan Minat Membaca Siswa Melalui Model Pembelajaran Kooperatif Tipe Tari Bambu Pada Kompetensi Dasar Menanggapi Isi Cerita Secara Lisan Bidang Studi Bahasa Indonesia Di Kelas Iii Sdn 060819 Kec. Medan Kota," Jurnal Penelitian, Pengabdian Dan Pemikiran 5, no. 2 (2017): 98-106, https://doi.org/Juli-Desember 2017.

${ }^{10}$ Nurma Tambunan, "Pengaruh Strategi Pembelajaran Dan Minat Belajar Terhadap Kemampuan Berpikir Kreatif Matematis Siswa," Formatif: Jurnal Ilmiah Pendidikan MIPA 6, no. 3 (2016): 207-19, https://doi.org/10.30998/formatif. v6i3.993. 
terdapat beberapa faktor yang dapat mempengaruhi munculnya minat belajar, yaitu: 1) motif, 2) perhatian, dan 3) bahan pelajaran dan sikap guru. Faktor yang mempengaruhi minat yang pertama adalah motif. Motif dapat diartikan sebagai upaya atau usaha yang merangsang seseorang untuk melakukan sesuatu. Motif dapat diartikan sebagai daya penggerak dari dalam untuk melakukan kreativitas tertentu demi mencapai suatu tujuan. Motif adalah kondisi dalam pribadi seseorang yang mendorong untuk melakukan suatu aktivitas tertentu untuk mendapatkan suatu tujuan. Faktor yang mempengaruhi minat yang kedua adalah perhatian. Perhatian adalah kesadaran yang menyertai sesuatu aktivitas yang dilakukan. Perhatian adalah pemusatan tenaga dan jiwa tertentu kepada suatu obyek, atau penggunaan kesadaran untuk menyertai suatu aktivitas. Faktor yang mempengaruhi minat yang ketiga adalah bahan pelajaran dan sikap guru. Materi pelajaran yang menarik minat siswa, akan sering dipelajari oleh siswa. Sebaliknya materi pelajaran yang tidak menarik minat siswa tentu akan dikesampingkan oleh siswa. ${ }^{11}$

Selanjutnya, strategi secara bahasa adalah ilmu siasat, tipu muslihat yang digunakan untuk mencapai tujuan tertentu. Secara istilah strategi diartikan sebagai garis besar haluan dalam bertindak untuk mencapai tujuan yang telah ditetapkan. ${ }^{12}$ Strategi pembelajaran merupakan suatu aktifitas pembelajaran yang harus dilakukan pendidik dan peserta didik supaya tujuan pembelajaran dapat dicapai secara efektif dan efesien. ${ }^{13}$ Strategi merupakan pedoman umum yang berisi komponen-komponen yang berbeda dari pembelajaran agar mampu mencapai tujuan yang diinginkan secara optimal di bawah kondisi-kondisi yang ditentukankan. ${ }^{14}$

11 Rusmiati, "Pengaruh Minat Belajar Terhadap Prestasi Belajar Bidang Studi Ekonomi Siswa Ma Al Fattah Sumbermulyo," Jurnal Ilmiah Pendidikan Dan Ekonomi 1, no. 1 (2017): 21-36.

12 Amidah, "Strategi Guru Dalam Meningkatkan Minat Belajar Siswa Pada Mata Pelajaran Pendidikan Agama Islam Di Sekolah Dasar Negeri 147 Palembang."

${ }^{13}$ Rusdiana Husain and Muzdalifah, "Penggunaan Strategi Role Play Dan Strategi Modeling the Way Dalam Pembelajaran Aqidah Akhlak Terhadap Hasil Belajar Siswa Kelas Iv Di Min Bawan Barabai" VII (2017): 167-96.

${ }^{14}$ Sufairi, "Pengaruh Strategi Pembelajaran Kooperatif Think Pair Share Dan Minat Belajar Terhadap Hasil Belajar Pendidikan Agama Islam Siswa Sekolah Dasar Negeri 104192 Tandem Hilir II Deli Serdang." 
Strategi pembelajaran dapat bersifat kompleks berdasarkan pada (1) tinggi tingkat tujuan dalam ranah kognitif, afektif dan keterampilan yang akan dicapai, (2) banyaknya dan telitinya persiapan yang dipilih, (3) tingkat berfikir yang dibutuhkan, (4) pengaturan kelas harus dilakukan secara menyeluruh, (5) hasil belajar yang sulit untuk dinilai. ${ }^{15}$

Cerita adalah seni dari para leluhur yang perlu dilestarikan dan dikembangkan sebagai salah satu cara untuk mendukung kepentingan sosial secara umum. Cerita adalah suatu cara sistematik dalam menyampaikan cerita atau dongeng untuk mencapai tujuan tertentu, yang dalam hal ini adalah untuk mengembangkan kecerdasan siswa. ${ }^{16}$ Cerita juga bisa diartikan sebagai uraian, gambaran atau deskripsi tentang peristiwa atau kejadian tertentu. Cerita merupakan aktivitas menuturkan sesuatu yang mengisahkan tentang perbuatan, pengalaman, atau kejadian yang sungguh-sungguh terjadi maupun hasil rekaan. Cerita yaitu salah satu seni, bentuk hiburan, dan pandangan tertua yang telah dipercayai nilainya dari generasi ke generasi berikutnya ${ }^{17}$. Strategi cerita adalah suatu strategi untuk menyampaikan materi kepada siswa seperti pristiwa atau kejadian dengan secara sistematis kepada siswa. Dengan begitu kita harus pandai memilih cerita atau dongeng yang mengandung pesan dan nilai positif bagi perkembangan kepribadian anak, baik secara psikologis maupun moral.

Penyajian strategi cerita terdapat beberapa tujuan, yaitu (1) menghibur para siswa agar menikmati cerita yang dikemas dengan ide yang menarik, imajinatif dan penyajian yang memukau bagi siswa. (2) menambah pengetahuan dan wawasan bagi siswa. Selain itu, penyajian strategi cerita juga dapat dilakukan yaitu: (1) menggunakan tata bahasa penyampaian yang indah sekaligus menambah perbendaharaan kosa kata siswa. (2) menumbuhkan daya khayal yang tinggi. (3) membersihkan akhlak. (4) mengasah cita (rasa). (5) melatih para

15 Marwoto, "Strategi Guru Sejarah Dalam Meningkatkan Minat Belajar Siswa Pada Mata Pelajaran Sejarah Di SMAN 10 Pekanbaru," Ilmu-Ilmu Sejarah, Budaya Dan Sosial, no. 1 (n.d.): 1-9.

16 T R I Wahyuni Wurdyastuti, "Kecerdasan Moral Siswa Di Sekolah Menengah Fakultas Psikologi," 2016.

17 Dewi, Marmawi, and Sutarmanto, "Strategi Guru Dalam Pembelajaran Mengembangkan Kemampuan Bercerita Pada Anak 5-6 Tahun Di TK," Pendidikan Guru, 2009, 1-15. 
siswanya untuk menyampaikan ide cerita dengan kata-kata atau dengan percakapan saja. ${ }^{18}$

Penggunaan strategi cerita terdapat beberapa tahapan, yaitu; (1) tahap persiapan yaitu guru melakukan pemilihan cerita berdasarkan tujuan, karakteristik siswa dan karakter sejarah, dalam hal ini ketika guru ingin bercerita harus memilih tema yang baik, jangan mengandung sara, tidak tergantung pada suatu golongan, mudah dipahami, dapat menumbuhkan semangat, cerita yang bagus dan menarik yang dipilih oleh guru harus internalisasi, dalam hal ini guru saat bercerita seakan-akan mengalami ataupun melihat peristiwa tersebut. (2) tahap penyajian, guru menyampaikan materi yang telah disiapkan dengan berinteraksi langsung pada siswa menggunakan strategi cerita. Menyampaikan cerita dengan gaya seolah-olah sedang melihat peristiwa yang disampaikan. (3) tahap evaluasi, dalam tahap evaluasi ini guru merangkum cerita dan menjawab beberapa pertanyaan dari siswa. Kemudian mempertegas terhadap materi dengan tujuan siswa benar-benar memahami kadungan cerita yag telah disampaikan. ${ }^{19}$

Manfaat dalam melakukan strategi cerita pembelajaran ini adalah: (1) mengembangkan imajinasi siswa; (2) menambah wawasan siswa; (3) melatih daya konsentrasi siswa; (4) menambah perbendaharaan kosa kata siswa; (5) Menciptakan suasana yang akrab; (6) Melatih daya ingat siswa; (7) Mengembangkan perasaan sosial siswa. ${ }^{20}$ Dalam penjelasan yang lain strategi cerita dalam pembelajaran mempunyai beberapa manfaat, yaitu: (1) meningkatkan keterampilan siswa dalam berbicara agar mengenal banyak kosakata. (2) menenangkan siswa, membaca dalam suasana santai dan nyaman, dengan menggunakan intonasi nada yang berbeda akan membuat siswa tertarik untuk mendengarkan cerita. kemudian siswa akan merasa nyaman dan berkurangnya tingkat stres pada siswa. (3) mengembangkan kemampuan siswa dalam berbahasa, dengan (n.d.): 1-14.

${ }^{18}$ Hajrah, "Pengembangan Metode Bercerita Pada Anak Usia Dini," no. 1

${ }^{19}$ Tadkiroatun Musfiroh, "Strategi Bercerita Cerita Sejarah," Agastya: Jurnal Sejarah Dan Pembelajarannya 1, no. 1 (2011): 47-61, https://doi.org/10.25273/ ajsp.v1i1.127.

${ }^{20}$ Uswatun Hasanah, "Strategi Pembelajaran Aktif Untuk Anak Usia Dini," INSANIA : Jurnal Pemikiran Alternatif Kependidikan 23, no. 2 (2019): 204-22, https://doi.org/10.24090/insania.v23i2.2291. 
mendengarkan struktur kalimat. Melalui cerita, siswa bisa belajar kosakata baru, belajar untuk mengekspresikan perasaan, seperti senang, sedih, maupun marah, serta dapat menyerap nilai-nilai kebaikannya. (4) meningkatkan minat baca pada siswa. (5) mengembangkan keterampilan berpikir pada siswa. (6) merangsang daya imajinasi dan kreativitas pada siswa. ${ }^{21}$

\section{Proses Pembelajaran PAI Menggunakan Strategi Cerita di SMP IT Al-Asror}

Analisis peneliti terhadap proses pembelajaran PAI di SMP IT AlAsror Sekampung Lampung Timur menggunakan strategi cerita. Strategi cerita merupakan salah satu strategi pembelajaran yang digunakan guru dalam pembelajaran PAI dengan tujuan pengalaman belajar bagi siswa. Cerita yang disajikan oleh guru secara lisan dalam materi PAI tema cerita yang disajikan guru berupa cerita sejarah kebudayaan Islam. Guru dalam menerapkan strategi cerita mengikuti beberapa prosedur yaitu; Pertama, guru bercerita langsung dari buku cerita dengan membacakan langsung dari buku cerita yang sesuai dengan materi pelajaran, dengan membacakan langsung dari buku cerita kepada siswa dapat mempermudah guru dalam menyampaikan materi pelajaran menggunakan strategi cerita terutama pesan-pesan yang tersirat di dalam cerita tersebut.

Kedua, guru bercerita dengan menggunakan ilustrasi gambar dari buku yang disampaikan pada siswa secara jelas dan terperinci. Penggunaan ilustrasi gambar dapat menarik perhatian siswa, sehingga strategi cerita ini akan terlaksana dengan baik. Penggunaan ilustrasi dapat mempermudah guru dalam menyampaikan materi yang sesuai kepada siswa dengan begitu siswa dapat memahmi materi yang diajarkan dengan baik. Dalam penggunaan ilustrasi guru harus mempersiapkan dan memilih ilustrasi yang sesuai dengan materi pelajaran agar siswa dapat memahami dan menangkap materi pelajaran dengan baik. Ketiga, guru menceritakan dongeng yang sesuai dengan materi pelajaran, bertujuan untuk meneruskan warisan budaya yang berupa nilai-nilai luhur dari satu generasi ke generasi yang berikutnya. Penggunaan dongeng dalam strategi cerita memiliki daya tarik bagi siswa untuk meningkatkan minat belajar siswa. Dalam hal ini

${ }^{21}$ Hajrah, "Pengembangan Metode Bercerita Pada Anak Usia Dini." 
guru harus menguasai isi cerita dalam dongeng dan materi pelajaran yang akan disampaikan.

Keempat, guru bercerita dengan menggunakan papan flanel. Menggunakan media papan flanel dapat memberikan pengalaman untuk siswa dengan menyajikan cerita secara lisan. Dalam hal ini guru menyajikan cerita secara menarik agar dapat menarik perhatian anak, disamping itu cerita menggunakan papan flanel seorang guru harus dapat memberikan pesan moral terhadap anak.

Kelima, guru bercerita dengan menggunakan media boneka. Meda boneka ditujukan untuk mewakili tokoh-tokoh cerita yang akan disampaikan. Dalam penggunaan media boneka guru membuat kelas kecil, agar guru lebih mendapatkan perhatian lebih dari anak, dan anakanak mendapatkan waktu yang lebih lama untuk mengggunakan media boneka, memperhatikan secara seksama dalam penggunaan media boneka. Penggunaan media boneka sebaiknya dilakukan dengan cerita yang tidak terlalu panjang dan jenis ceritanya diusakan cerita yang berbentuk fabel.

Kendala guru dalam proses pembelajaran PAI menggunakan strategi cerita ini yaitu: (1) guru dalam menyiapkan cerita belum sesuai dengan materi pembelajaran yang akan disampaikan, (2) guru lebih dominan dalam proses pembelajaran, (3) siswa menjadi tidak aktif (4) guru dalam pembelajaran belum menguasai bahan cerita dengan materi, (5) pemahaman anak menjadi sulit ketika sudah terfokus dengan masalah lain, (6) menjadikan anak merasa jenuh (7) sering terjadi ketidakselarasan isi cerita dengan materi.

Selain kendala di atas, dalam proses pembelajaran PAI juga terdapat kendala yang lain yaitu dimana peserta didik lebih fokus terhadap jalannya cerita itu sendiri, jadi peserta didik tidak dapat mengambil inti dari pembahasan materi ataupun cerita tersebut, dalam hal ini peserta didik menjadi pasif karena guru yang lebih aktif, biasanya peserta didik lebih cenderung hafal dengan jalannya cerita dibandingkan dengan isi atau inti dari materi tersebut.

\section{Pengaruh Strategi Cerita Terhadap Minat Belajar Siswa di SMP IT Al-Asror}

Penggunaan strategi cerita dalam pembelajaran mampu memberikan pengaruh terhadap minat belajar siswa secara signifikan. Minat belajar siswa sebelum diterapkan strategi cerita masih relatif 
rendah. Dari survei awal ditemukan tingkat minat belajar siswa berada pada rata-rata 40 yaitu pada rentang rendah.

Proses pembelajaran dengan menggunakan strategi cerita menjadikan siswa merasa lebih senang dan gembira sehingga meningkatkan minat belajar yang tinggi yang berimbaskan pada hasil belajar siswa. Dengan strategi cerita, siswa merasa lebih asyik dan tidak cepat merasa bosan, dengan begitu maka siswa akan menjadi lebih bersemangat dalam mengikuti pembelajaran. Analisis data pada penelitian ini dibagi menjadi dua yaitu uji prasyarat dan uji hipotesis. Uji prasyarat yang digunakan yaitu uji normalitas dan uji homogenitas. Berikut ini hasil uji normalitas dengan SPSS.

\section{Tabel 1. Uji Normalitas}

Tests of Normality

\begin{tabular}{|c|c|c|c|c|c|c|c|}
\hline & & \multicolumn{3}{|c|}{ Kolmogorov-Smirnova } & \multicolumn{3}{|c|}{ Shapiro-Wilk } \\
\hline & kode & Statistic & Df & Sig. & Statistic & Df & Sig. \\
\hline \multirow[t]{2}{*}{ Nilai } & 1 & ,117 & 30 & ,200* & ,963 & 30 & ,359 \\
\hline & 2 & ,110 & 30 & ,200* & ,945 & 30 & ,126 \\
\hline $\begin{array}{l}* \text {. Thi } \\
\text { a. Lill }\end{array}$ & $\begin{array}{l}\text { lower } \\
\text { s Signi }\end{array}$ & $\begin{array}{l}\text { und of the } \\
\text { ance Correc }\end{array}$ & signi & & & & \\
\hline
\end{tabular}

Pada tabel diatas diketaui bahwa nilai sig (kolmogorov-smirnov) pada data nilai pretes dan prostes yaitu bernilai sama 0,200 . Taraf signifikansi yang digunakan dalam pengujian ini yaitu $\alpha=5 \%=0,05$. Hal tersebut menunjukkan bahwa nilai sig hitung $>\alpha$ sehingga $\mathrm{H} 0$ diterima. Kesimpulan pada uji normalitas yaitu sample berasal dari populasi yang berdistribusi normal.

Setelah dilakukan uji normalitas maka dilanjutkan dengan uji homogenitas. Tabel berikut ini menunjukkan hasil uji homogenitas dengan SPSS.

Tabel 2. Uji Homogenitas

\begin{tabular}{llrrrr}
\multicolumn{7}{c}{ Test of Homogeneity of Variances } & & \\
\hline \multirow{2}{*}{ Nilai } & Levene Statistic & df1 & df2 & \multicolumn{1}{c}{ Sig. } \\
& Based on Mean &, 028 & 1 & 58 &, 867 \\
& Based on Median &, 007 & 1 & 58 &, 935 \\
Based on Median and with &, 007 & 1 & 57,309 &, 935 \\
adjusted df & & & & \\
Based on trimmed mean &, 027 & 1 & 58 &, 870 \\
\hline
\end{tabular}

Pada tabel diatas diketaui bahwa nilai sig (levene statistic) pada data nilai pretes dan prostes yaitu bernilai 0,867 . Taraf signifikansi 
yang digunakan dalam pengujian ini yaitu $\alpha=5 \%=0,05$. Hal tersebut menunjukkan bahwa nilai sig hitung $>\alpha$ sehingga HO diterima. Kesimpulan pada uji homogenitas yaitu varians data homogen.

Hasil analisis data angket pada siswa menunjukkan terjadinya peningkatan terhadap minat belajar PAI siswa secara signifikan. Untuk mengetahui stratetegi cerita dalam pembelajaran PAI apakah mampu memberikan pengaruh terhadap minat belajar PAI dilakukan uji T. Hasil uji T pada taraf signifikan $\alpha=5 \%=0,05$ dengan hasil uji: jika sig hitung $>\alpha$ maka HO diterima.

Tabel 3. Uji T

Independent Samples Test

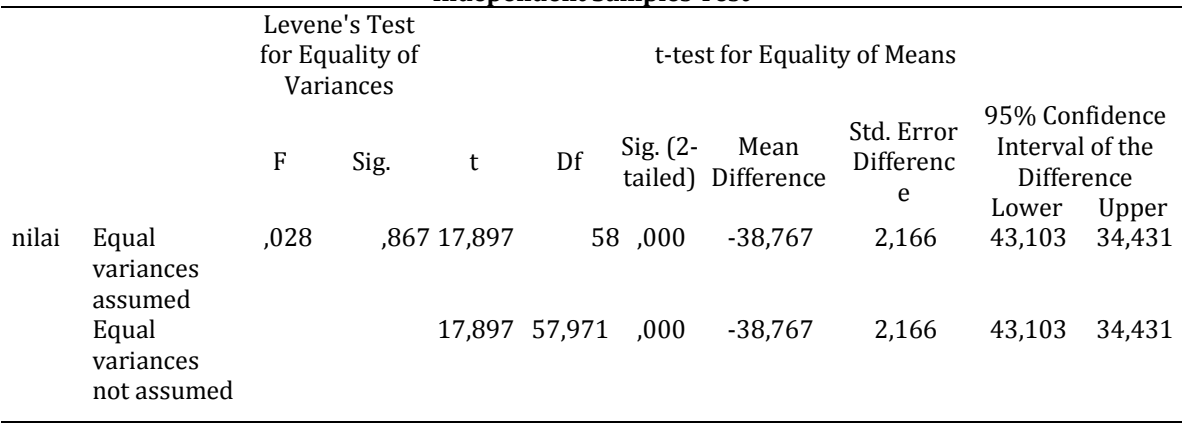

Dari tabel diatas dapat diketahui nilai sig (2-tailed) hitung yaitu 0,000 dengan keputusan uji nilai sig hitung $<\alpha$ sehingga Ho ditolak dan menerima H1. Dari hasil ini berarti bahwa penggunaan strategi cerita dalam pembelajaran PAI mampu memberikan pengaruh terhadap minat belajar PAI siswa di SMP IT Al-Asror Sekampung Lampung Timur.

Hasil penelitian di atas menunjukkan bahwa penggunaan strategi cerita dapat meningkatkan minat belajar PAI siswa di SMP IT Al-Asror Sekampung Lampung Timur. Peningkatan minat dicapai sejalan dengan penerapan strategi cerita yang mengikuti prosedur secara optimal. Pembelajaran dengan menggunakan strategi cerita dapat membuat suasana kelas menjadi lebih hidup dan menyenangkan bagi siswa sehingga akan meningkatnya minat belajar PAI siswa. Dengan menerapkan strategi cerita pada pembelajaran PAI, maka akan menghilangkan rasa jenuh dan bosan bagi siswa dengan strategi pembelajaran yang monoton. Penggunaan strategi cerita sebagai metode dalam pembelajaran diakhiri dengan evaluasi yang dilakukan 
oleh guru. Proses evaluasi didasarkan pada proses pembelajaran sebagai dampak dari minat belajar yang tinggi sebagai pengaruh dari penerapan strategi cerita.

Penggunaan strategi cerita dalam pembelajaran PAI dapat memberikan kemudahan pada siswa. Dalam meggunakan strategi cerita di awali dengan guru memberikan sebuah cerita kepada siswa berkaitan dengan materi yang akan diajarkan, kemudian guru memberi waktu untuk tanya jawab antara guru dan siswa terhadap materi yang telah di ajarkan. Guru memberikan kesempatan beberapa siswa untuk menjelaskan kembali materi yang telah dijelaskan didepan kelas yang bertujuan untuk melatih keberanian dan kepercayaan diri siswa. Keberhasilan pembelajaran PAI dengan menggunakan strategi cerita sangat ditentukan oleh keprofesionalan guru dalam proses pengajaran. Guru harus memiliki sikap keterbukaan, menerima pertanyaan, kritik dan saran.

Proses pembelajaran PAI tidak terlepas dari problema dalam penggunaan strategi cerita. Dalam penggunaan strategi cerita teradapat tiga kendala yaitu: (1) Siswa belum memiliki tingkat keinginan dan semangat yang sama dalam mendengarkan cerita. Keingintahuan dalam diri siswa juga berbeda-beda hal ini terlihat dari konsentrasi siswa yang beragam diantara siswa yang lainnya. Maka tugas guru adalah guru harus mengenal karakteristik para siswa nya, misal nya guru tersebut mengajar di daerah jawa maka sebaiknya guru juga menyisipkan kata-kata jawa untuk menarik perhatian para siswa nya agar mempunyai keinginan dalam mendengarkan cerita. (2) Dalam penggunaan strategi cerita kemapuan guru masih terbatas sehingga penggunaan waktu tidak efesien. Maka guru sebaiknya menyiapkan materi dengan baik dan sesuai dengan strategi yang akan dilakukan dalam pembelajaran agar siswa dapat memahami materi pelajaran dengan baik menggunakan strategi cerita. (3) Pada saat yang sama hubungan sarana prasaran sekolah tidak sepenuhnya memadai. Penggunaan strategi cerita perlu juga didukung lingkungan kelas yang kondusif seperti ketersediaan kipas angin, ruang kelas yang bersih dan nyaman, fentilasi udara yang sehat agar membantu kelancaraan pelaksanaa strategi cerita pada proses pembelajaran.

Penelitian ini berbeda dari penelitian sebelumnya yang lebih menekankan pada hasil belajar PAI. Penelitian ini lebih menekankan pada proses pembelajaran dengan melibatkan siswa aktif melalui penggunaan strategi cerita. Cerita yang dikemas oleh guru harus sesuai 
dengan usia siswa, agar siswa lebih terfokus dan tertarik dengan penggunaan strategi cerita sehingga dapat meningkatkan minat belajar siswa.

\section{E. Kesimpulan}

Penelitian ini menunjukkan bahwa yang selama ini dirasakan tentang minat belajar PAI yang rendah tidak terdapat alasan yang mendasar. Peneliti ini menghasilkan temuan bahwa tingkat minat belajar PAI yang tinggi setelah menggunakan strategi cerita. Peningkatan minat belajar ini dikarenakan materi cerita sesuai dengan usia siswak dan disampaikan dengan alur yang menarik. Minat belajar PAI yang tinggi menimbulkan konsentrasi dalam memper-hatikan alur cerita yang disampaikan guru sehingga berpengaruh pada hasil belajar PAI.

Pembelajaran berbasis cerita dalam pembelajaran PAI telah mampu menjawab problema kesulitan belajar PAI di SMP. Problem yang disebabkan rendah nya hasil belajar kemudian pembelajaran berpusat pada guru, minat belajar yang rendah dapat diatasi dengan strategi cerita. Proses pembelajaran PAI tidak hanya terkait pada hasil saja tetapi juga terkait aspek proses yang didorong oleh penggunaan strategi cerita. Penggunaan strategi cerita dalam proses pembelajaran PAI telah menarik minat belajar siswa, siswa merasa lebih senang dan tidak cepat bosan dalam pembelajaran sehingga tujuan pembelajaran dapat dicapai dengan mudah.[]

\section{Daftar Pustaka}

Amidah, A. "Strategi Guru Dalam Meningkatkan Minat Belajar Siswa Pada Mata Pelajaran Pendidikan Agama Islam Di Sekolah Dasar Negeri 147 Palembang." Conciencia 14, no. 2 (2014): 117-38. https://doi.org/ 10.19109/conciencia.v14i2.98.

Amirudin, Noor. "Problematika Pembelajaran Pendidikan Agama Islam Di Era Digital." Prosiding Seminar Nasional PAI Dengan Pendekatan Multidisipliner, 2019, 181-92. 
Dewi, Marmawi, and Sutarmanto. "Strategi Guru Dalam Pembelajaran Mengembangkan Kemampuan Bercerita Pada Anak 5-6 Tahun Di TK." Pendidikan Guru, 2009, 1-15.

Dewi, Tiara anggia. "Pengaruh Profesionalisme Guru Dan Motivasi Kerja Terhadap Kinerja Guru Ekonomi Sma Se-Kota Malang." PROMOSI (Jurnal Pendidikan Ekonomi) 3, no. 1 (2015): 24-35. https://doi.org/ 10.24127/ja.v3i1.148.

Friska, Lestari. "Meningkatkan Konsentrasi Belajar Siswa Dengan Menerapkan Pembelajaran Kontekstual Pada Pembelajaran Ipa," 2017.

Hajrah. "Pengembangan Metode Bercerita Pada Anak Usia Dini," no. 1 (n.d.): 1-14.

Hasanah, Uswatun. "Strategi Pembelajaran Aktif Untuk Anak Usia Dini." INSANIA : Jurnal Pemikiran Alternatif Kependidikan 23, no. 2 (2019): 204-22. https://doi.org/10.24090/insania.v23i2.22 91.

Husain, Rusdiana, and Muzdalifah. "Penggunaan Strategi Role Play Dan Strategi Modeling the Way Dalam Pembelajaran Aqidah Akhlak Terhadap Hasil Belajar Siswa Kelas Iv Di Min Bawan Barabai" VII (2017): 167-96.

Marwoto. "Strategi Guru Sejarah Dalam Meningkatkan Minat Belajar Siswa Pada Mata Pelajaran Sejarah Di SMAN 10 Pekanbaru." Ilmu-Ilmu Sejarah, Budaya Dan Sosial, no. 1 (n.d.): 1-9.

Musfiroh, Tadkiroatun. "Strategi Bercerita Cerita Sejarah." Agastya: Jurnal Sejarah Dan Pembelajarannya 1, no. 1 (2011): 47-61. https://doi.org/ 10.25273/ajsp.v1i1.127.

Rosidah. "Upaya Meningkatkan Minat Membaca Siswa Melalui Model Pembelajaran Kooperatif Tipe Tari Bambu Pada Kompetensi Dasar Menanggapi Isi Cerita Secara Lisan Bidang Studi Bahasa Indonesia Di Kelas Iii Sdn 060819 Kec. Medan Kota." Jurnal 
Penelitian, Pengabdian Dan Pemikiran 5, no. 2 (2017): 98-106. https://doi.org/ Juli-Desember 2017.

Rusmiati. "Pengaruh Minat Belajar Terhadap Prestasi Belajar Bidang Studi Ekonomi Siswa Ma Al Fattah Sumbermulyo." Jurnal Ilmiah Pendidikan Dan Ekonomi 1, no. 1 (2017): 21-36.

Sinaga, Sopian. "Problematika Pendidikan Agama Islam Di Sekolah Dan Solusinya" II, no. 1 (2017): 175-88.

Sufairi. "Pengaruh Strategi Pembelajaran Kooperatif Think Pair Share Dan Minat Belajar Terhadap Hasil Belajar Pendidikan Agama Islam Siswa Sekolah Dasar Negeri 104192 Tandem Hilir II Deli Serdang" 3, no. 1 (2019): 129-39.

Susiana, Susiana. "Problematika Pembelajaran PAI Di SMKN 1 Turen." Jurnal Pendidikan Agama Islam Al-Thariqah 2, no. 1 (2017): 7388. https://doi.org/10.25299/althariqah.2017.vol2(1).648.

Tambunan, Nurma. "Pengaruh Strategi Pembelajaran Dan Minat Belajar Terhadap Kemampuan Berpikir Kreatif Matematis Siswa." Formatif: Jurnal Ilmiah Pendidikan MIPA 6, no. 3 (2016): 20719. https://doi.org/10.30998/formatif.v6i3.993.

Wurdyastuti, T R I Wahyuni. "Kecerdasan Moral Siswa Di Sekolah Menengah Fakultas Psikologi," 2016.

Yunof Candra, Bach. "Problematika Pendidikan Agama Islam." Journal ISTIGHNA 1, no. 1 (2019): 134-53. https://doi.org/10.33853/ istighna.v1i1.21. 